1999

\title{
Emotional Intelligence and Legal Education
}

Marjorie A. Silver

Touro Law Center, msilver@tourolaw.edu

Follow this and additional works at: https://digitalcommons.tourolaw.edu/scholarlyworks

Part of the Legal Profession Commons, and the Psychiatry and Psychology Commons

\section{Recommended Citation}

54(4) Psychol., Pub. Pol'y, \& L. 1173

This Article is brought to you for free and open access by the Faculty Scholarship at Digital Commons @ Touro Law Center. It has been accepted for inclusion in Scholarly Works by an authorized administrator of Digital Commons @ Touro Law Center. For more information, please contact Iross@tourolaw.edu. 


\title{
EMOTIONAL INTELLIGENCE AND LEGAL EDUCATION
}

\author{
Marjorie A. Silver \\ Touro College Law Center
}

The traditional knowledge-based law school curriculum is slowly giving way to one that increasingly exposes students to various lawyering skills. Nonetheless, legal educators are generally averse - or at best ill equipped - to support that training with the empathic and psychological skills good lawyering demands. The author discusses how emotional intelligence is essential to good lawyering and argues that it can and should be cultivated in law school. The article draws upon three examples of popular culture to explore both the absence and possibilities of interpersonal intelligence in the practice of law. The author also describes her own law school's current project of re-imagining legal education and explains how the development of emotional skills might be incorporated into that vision.

\section{Introduction}

A baby cries. Another infant, observing the first, also cries.

Tim, a toddler, begins to cry. Tom, another toddler, goes to his own mother, tugs at her shirt, and points to Tim. Tom's mother picks Tim up to soothe him, and Tom smiles.

A client breaks down in tears in the office of his divorce lawyer. The lawyer hands him a box of tissues and tells him that she knows how hard this must be. "Take your time," she says. "How about I do some paperwork until you feel like you can talk again, okay?"

. Is there a commonality here? In all three examples, emotional intelligence is on display. The baby, the toddler, and the lawyer all demonstrate that they are tuned in to the emotional distress of another and respond to that display with empathy. For the baby, this is quite literal: you cry; I cry. For the toddler, a more sophisticated response: "I know what would make me feel better, and I bet it would make you feel better, too: My Mommy." Such responses on

*This article had its genesis in one section of a larger piece, Marjorie A. Silver, Love, Hate and Other Emotional Interference in the Lawyer/Client Relationship, 6 CLIN. L. REv. 259 (1999).

I wish to thank my invaluable research assistant, Sandra Maliszewski, and the professional Touro Library staff. My gratitude, too, for the resource contribution of my former student, Lawrence DeAngelis. I also thank my colleagues past and present on the Central Islip Program Planning Committee for their collaboration in reconceiving our educational program. Among those, I especially wish to acknowledge my friends and colleagues, Jack Battaglia and Eileen Kaufman, who not only gave me essential feedback on a draft of this article, but from whose vision of legal education I borrow liberally.

Work on this article has been funded by a Touro Law Center faculty research grant.

Correspondence concerning this article should be addressed to Marjorie A. Silver, Professor of Law, Touro College Law Center, 300 Nassau Road, Huntington, New York 11743. Electronic mail may be sent to msilver345@hotmail.com. 
behalf of babies and toddlers are developmentally appropriate, generally expected behavior. ${ }^{1}$

Something happens between toddler-dom and lawyer-dom, however. By the time one graduates from law school, empathic abilities may seldom be in evidence. The response of the lawyer in the example above is likely to be the exception, not the rule. Other lawyers may be watching their watches, calculating how much time their client's emotional display is likely to take, and worrying about the next appointment. Other lawyers might respond to tears with reassurances that the client's case is strong, the legal arguments solid; therefore, there is nothing about which to be distressed.

By the time one graduates from law school the skills that have been validated rarely include emotional, empathic intelligence. To reason, to analyze, to distinguish, to draw analogies, to speak and write well-these are the qualities of the successful law graduate. Only recently has legal education awoken to the need to better prepare new lawyers for other aspects of the practice of law, such as counseling, negotiation, and drafting. Increasing numbers of law schools are adding such "skill" courses to their basic-if not required-curriculum. Yet even here, the skill to know when to offer a box of tissues to a client, to give the client room to mourn the loss of a relationship, are seldom identified, rarely taught, and perhaps never assessed as part of the students' overall competency at lawyering.

This is unfortunate, and it can and should be addressed. Legal education should prepare students for the emotional dimensions of lawyering. We fail our students if we fail to prepare them for the impact of their emotional lives, as well as those of their clients, on the practice of law. Legal education should cultivate emotional intelligence. ${ }^{2}$

In Part II, I explain the importance of emotional intelligence, giving a brief overview of intelligence as traditionally understood and as presented by Howard

\footnotetext{
${ }^{1}$ See Daniel Goleman, Emotional Intelligence 98 (paperback ed. 1997):

Developmental psychologists have found that infants feel sympathetic distress even before they realize that they exist apart from other people. Even a few months after birth, infants react to a disturbance in those around them as though it were their own, crying when they see another child's tears. By one year or so, they start to realize the misery is not their own but someone else's, though they still seem confused over what to do about it. In research by Martin L. Hoffman at New York University, for example, a one-year-old brought his own mother over to comfort a crying friend, ignoring the friend's mother, who was also in the room. This confusion is seen too when one-year-olds imitate the distress of someone else, possibly to better comprehend what they are feeling; for example, if another baby hurts her fingers, a one-year-old might put her own fingers in her mouth to see if she hurts, too. On seeing his mother cry, one baby wiped his own eyes, though they had no tears.
}

Helene Borke, Interpersonal Perception of Young Children, 5 Develópment Psychology 263-69 (1971) (demonstrating empathic abilities of young children); Marvin L. Simner, Newborn's Response to the Cry of Another Infant, 5 DeVELOPMENT PSYCHOLOGY 136-50 (1971) (demonstrating causal effect among crying of newborns).

${ }^{2}$ The phrase "cultivating intelligence" is the title of a wonderful book by two of my dearest colleagues on how and why we teach what we teach in law school. LOUISE HARMON \& DEBORAH W. Post, Cultivating Intelligence: Power, Law, and the Politics of Teaching (1996). Although I would count both colleagues as being blessed with both intrapersonal intelligence (as evidenced by their introspective book) and interpersonal intelligence (as evidenced by their nurturing support of their students and their colleagues), the importance of cultivating emotional intelligence is not explicit in the work itself. 
Gardner in his theory of multiple intelligences. ${ }^{3}$ Gardner wrote of both intra- and interpersonal intelligences. ${ }^{4}$ These "personal" intelligences are basically what Peter Salovey and John Mayer have identified as "emotional intelligence." 5 This is further popularized by Daniel Goleman in his best-selling trade publication, Emotional Intelligence. ${ }^{6}$

In Part III, I explore the relationship between emotional intelligence, lawyering, and legal education. I note the resistance among lawyers to acknowledge the importance of the emotions in the practice of law. In Part III.A., I discuss two plays (one recent, ${ }^{7}$ one old ${ }^{8}$ ), a film, ${ }^{9}$ and the work of two law professors, Susan Daicoff, in work she has done over the past few years (as well as in this theme issue $\left.^{10}\right),{ }^{11}$ and Andrew Watson, writing approximately 30 years ago, ${ }^{12}$ as vehicles and opportunities for examining the importance of cultivating emotional skills in law school. I also suggest in Part III.A. that as the profession moves away from an adversarial model to one more focused on problem solving by alternative means, the importance of cultivating emotional intelligence increases.

In Part III.B., I describe my own law school's current undertaking to rethink our curriculum in anticipation of a move to a new facility and the opportunities presented by this project to enhance knowledge, skills, and values informed by an understanding and appreciation of the significance of intra- and interpersonal skills.

In Part III.C., I imagine some alternative stories we might tell about lawyering informed by a foundation of emotional intelligence.

\section{Discussion of the Intelligences}

\section{A. Traditional Theory}

Although a variety of theorists have offered a multiplicity of definitions for what we call intelligence, what we generally mean by that term is usually quite narrow. The most traditional and most narrow definition is that which we measure

${ }^{3}$ See Howard Gardner, Multiple Intelligences: The Theory in Practice (1993); Howard GaRdNER, Frames of Mind (1983).

${ }^{4}$ Gardner, Multiple Intelligences, at 9; Gardner, Frames of Mnd, at 239-40.

${ }^{5}$ Peter Salovey \& John D. Mayer, Emotional Intelligence, 9(3) IMAGINATION, CognITION AND Personality 185 (1989-90).

${ }^{6}$ See Goleman, supra note 1.

${ }^{7}$ Excerpts from WIT by Margaret Edson. Copyright 1993, 1999 by Margaret Edson. Reprinted by permission of Faber and Faber, Inc., an affiliate of Farrar, Straus and Giroux, LLC.

${ }^{8}$ Terence Rattigan, The Winslow Boy (1946). Copyright 1946, 1973, Terence Rattigan. Reprinted by permission of Dramatists Play Service, Inc. I became acquainted with this play on seeing the recent David Mamet film of the same name. THE WinsLow Boy (Sony Pictures Entertainment, Inc. 1999).

${ }^{9}$ Patch AdAms (Universal Studios 1999).

${ }^{10}$ See Susan Daicoff, Making Law Therapeutic for Lawyers: Therapeutic Jurisprudence, Preventive Law, and the Psychology of Lawyers, 5 Psychol. Pub. PoL'y \& L. 811 (1999).

${ }^{11}$ Susan Daicoff, Asking Leopards to Change Their Spots: Should Lawyers Change? A Critique of Solutions to Problems With Professionalism by Reference to Empirically-Derived Attorney Personality Attributes, 11 Geo. J. LegAL ETHICs 547 (1998); Susan Daicoff, Lawyer, Know Thyself: A Review of Empirical Research on Attorney Attributes Bearing on Professionalism, 46 AM. U. L. REV. 1337 (1997).

${ }^{12}$ Andrew S. Watson, The Quest for Professional Competence: Psychological Aspects of Legal Education, 37 Univ. CinN. L. Rev. 91 (1968). 
by a standardized intelligence quotient (I.Q.) examination. ${ }^{13}$ Intelligence is regarded generally as the qualities one needs to succeed in academics. Those qualities largely are measured by administration of short-answer and standardized examinations. ${ }^{14}$

\section{B. Gardner's Theories}

In his pathbreaking 1983 book, Frames of Mind $^{15}$ the psychologist and educator Howard Gardner identified seven independent intelligences, ${ }^{16}$ two of which are interpersonal and intrapersonal intelligence. ${ }^{17}$ Gardner defined them as follows:

Interpersonal intelligence is the ability to understand other people: what motivates them, how they work, how to work cooperatively with them. Successful sales people, politicians, teachers, clinicians, and religious leaders are all likely to be individuals with high degrees of interpersonal intelligence. Intrapersonal intelligence, a seventh kind of intelligence, is a correlative ability, turned inward. It is a capacity to form an accurate, veridical model of oneself and to be able to use that model to operate effectively in life. ${ }^{18}$

In a 1990 article, ${ }^{19}$ Peter Salovey and John Mayer advanced the case for the

\footnotetext{
${ }^{13}$ For a brief history of how the IQ test was developed by Alfred Binet in Paris a century ago, see GaRdNeR, Multiple INTELliGenCES, supra note 3, at 5.

${ }^{14}$ See Howard Gardner \& Thomas Hatch, Multiple Intelligences Go to School, 18 EDUCATIONAL. RESEARCHER 4, 5 (1989):

Most definitions of intelligence focus on the capacities that are important for success in school. Problem solving is recognized as a crucial component, but the ability to fashion a product - to write a symphony, execute a painting, stage a play, build up and manage an organization, carry out an experiment-is not included, presumably because the aforementioned capacities cannot be probed adequately in short-answer tests.
}

${ }^{15}$ Gardner, Frames of Mind, supra note 3.

${ }^{16} \mathrm{Gardner}$ defined an intelligence as "the ability to solve problems, or to fashion products, that are valued in one or more cultural or community settings." Id. at 7 .

${ }^{17}$ The other five are musical intelligence; bodily-kinesthetic intelligence; logical-mathematical intelligence; linguistic intelligence; and spatial intelligence. GARDNER, MultiPLE InTELLIGENCES, supra note 3, at 17-26; GARDNER, FrAMES OF MiND, supra note 3, at 73-276. Gardner has since added an eighth: naturalist intelligence, and a possible ninth: existential intelligence. Because he still had reservations about whether the latter fits within his definition of an intelligence, Gardner, in deference to the film by director, Federico Fellini, has called them the " $81 / 2$ " intelligences. Howard Gardner, Lecture at the New York Public Library on The Disciplined Mind: What All Students Should Understand (1999) (May 25, 1999). See Gardner \& Hatch, supra note 14, at 6.

${ }^{18}$ GaRdNer, Multiple INTELLigences, supra note 3 , at 9 . Note that lawyers are conspicuously absent from his examples of professions whose members are likely to have strengths in interpersonal intelligence.

Gardner further described intrapersonal intelligence as

knowledge of the internal aspects of a person: access to one's own feeling life, one's range of emotions, the capacity to effect discriminations among these emotions and eventually to label them and to draw upon them as a means of understanding and guiding one's own behavior. A person with good intrapersonal intelligence has a viable and effective model of himself or herself.

Id. at $24-25$.

${ }^{19}$ Salovey \& Mayer, supra note 5. 
legitimacy of emotional intelligence as one of the intelligences ${ }^{20}$ and its importance to mental health. ${ }^{21}$ Furthermore, the authors emphasized the connection between emotional intelligence and empathy, the latter being a quality that invokes positive responses in others, the absence of which provokes the opposite. $^{22}$ Surveying a number of "empathy researchers," Salovey and Mayer explained the dependence of empathy on the skills necessary for appreciating and appropriately articulating emotion. ${ }^{23}$

Salovey and Mayer recognized that the skills needed for emotional actualization may be more highly developed in some than in others, but they also may be skills that can be taught and learned, thereby contributing to mental health. ${ }^{24}$ Goleman's work--written for a general audience ${ }^{25}$ - took this further, promoting

${ }^{20}$ Id. at $189:$

We define emotional intelligence as the subset of social intelligence that involves the ability to monitor one's own and others' feelings and emotions, to discriminate among them and to use this information to guide one's thinking and actions. (emphasis in original)

${ }^{21} / d$. at 201:

The person with emotional intelligence can be thought of as having attained at least a limited form of positive mental health. ... [E]motionally intelligent individuals accurately perceive their emotions and use integrated, sophisticated approaches to regulate them as they proceed toward important goals.

${ }^{22} I d$. at 195 :

We have included the skillful recognizance of others' emotional reactions and empathic responses to them as a component of emotional intelligence. These skills enable individuals to gauge accurately the affective responses in others and to choose socially adaptive behaviors in response. Such individuals should be perceived as genuine and warm by others, while individuals lacking these skills should appear oblivious and boorish.

${ }^{23}$ Id. at 194-95:

[These qualities include the ability] to understand another person's point of view, to identify accurately another's emotions, to experience the same or other appropriate emotion in response to them, and finally, to communicate and/or act on this internal experience.

(sources deleted). But see Robert Epstein, The Key to Our Emotions, Psychology ToDAy 20 (July/August 1999). In this interview with Jack Mayer, Salovey's co-author described emotional intelligence as "a group of mental abilities which help you recognize and understand your own feelings and others [that] leads to the ability to regulate your feelings," characterizing emotional intelligence as both "the intellect understanding emotion [and] emotion reaching into the intellectual system and bringing about creative thoughts and ideas." This seems somewhat at variance with the 1996 article. Mayer criticized the "popular presentation" of emotional intelligence and those who view emotional intelligence as "a list of traits such as optimism, persistence and warmth. ... It is true that some salespeople can be helped by being optimistic and extroverted and so forth. But that's not necessarily a requirement for lawyers or teacher." $I d$. As both a lawyer and a teacher, I find Mayer's dichotomous stereotyping problematic. See discussion, infra, text at notes 98-102.

${ }^{24} I d$. at 191 .

${ }^{25}$ And successfully so. The book held a place on The New York Times bestseller list for many months. See Warren Bennis, It Ain't What You Know, N.Y. TIMEs Book Review, Oct. 25, 1998, at 50 (book review of Daniel Goleman, Working With Emotional Intelligence (1998), describing Goleman as the author of the "hugely popular" Emotional Intelligence); James Traub, Multiple Intelligence Disorder, THE NEW REPUBLIC, Oct. 26, 1998, at 20, 21 (describing book as "wildly popular'). 
the actualization of emotional intelligence as a blueprint for living. ${ }^{26}$ His book explored at length a variety of life situations where the absence of emotional intelligence may diminish the quality of life generally and of relationships in particular. He explored anger, intimate relationships, and management skills, each as windows of opportunity for the exercise of emotional skills. Although he discussed how development of such skills may be woven into the elementary school curriculum-noting in particular some of the initiatives of Gardner and others-his book stops short of exploring how emotional skills might be developed in postsecondary, graduate, or professional education. ${ }^{27}$

Goleman defined emotional intelligence as "abilities such as being able to motivate oneself and persist in the face of frustrations; to control impulse and delay gratification; to regulate one's moods and keep distress from swamping the ability to think; to empathize and to hope." 28 But much of his definition borders on the defensive: how to keep emotions from mucking things up.

To me, more important are the positive implications of emotional intelligence. Emotional intelligence includes knowledge and appreciation of one's own emotional life and sensitivity to and acceptance of the emotional lives of others. It is an attitude that acknowledges the legitimacy of emotions and their relevance to our actions, interactions, and decisions. Its actualization requires the intra- and interpersonal skills necessary to live a joyful and connected life, rich in personal relationships.

\section{Academic Versus Life Success}

A personal story. I was first in my high school class, summa cum laude in college and magna cum laude in law school. I state that not to boast but to locate myself as academically inclined-an academic high achiever. In fact, for more than half of my life I measured success largely by academic achievement and visited those values on my firstborn, my son, Josh.

Josh was a good student, not a great student. He was academically responsible, but not academically driven as I had been. Often, he did not work as hard at his school work as I thought he should.

This came to a head during his freshman year of high school, spring semester. His work slacked off, and his semester grades reflected that: he pulled the lowest average he had thus far, a B-, as I recall.

Phil Allen, then the head of the upper school that Josh attended, invited parents to come meet with him that June to discuss their young person's past year. Josh's dad and I attended. Phil began our conversation by asking, "So, what kind of year do you think Josh has had?" Bursting with negativity, I immediately started talking about Josh's disappointing grades, about his failure to apply himself sufficiently to his studies. Phil cut me off. "Really?" he asked. "We think Josh has had a wonderful year." He then talked about how Josh had matured socially, about the friendships he had formed, the student

\footnotetext{
${ }^{26}$ See GolEMAN, supra note 1.

${ }^{27}$ The closest he comes in this regard is an entreatment that medical school should help develop emotional intelligence among doctors-in-training. See infra note 68 .

${ }^{28}$ Goleman, supra note 1 , at 34 .
} 
activities he had led, about his emotional courage (Josh developed scoliosis, which required major surgery and the wearing of a heavy brace for more than 2 years). I quickly realized that all of this was true, that had I paid attention I would have realized it was true. I just hadn't deemed it especially important to Josh as a student, at least not in comparison to the disappointment of Josh's (relative to me) academic laxity.

It was then that I began to open up to the possibilities of alternative kinds of excellence. I gradually learned to celebrate my son's strengths and relinquished my projection onto him of the primacy of academics. Ironically, Josh went on to attend Swarthmore, a highly competitive small liberal arts college that had been my first choice when I applied to college (and I hadn't been accepted!), and he blossomed like springtime in Swarthmore's renowned campus arboretum. Each semester he committed to learn (and accomplished) at least one new skill or talent: fencing, diving, tap dancing, emceeing a radio show, running his dorm's breakfast room, serving as resident advisor. He graduated with no academic honors, yet with the equipment to achieve a rich life full of meaning, caring, and loving. He found his calling in teaching, and he now teaches history at a private middle and upper school much like the one he attended. Not surprisingly, he is a wonderfully committed and creative teacher.

We value academic achievement in our culture, and yet it is such a small part of what ultimately determines success in life. ${ }^{29}$ If we work hard in school and get good grades-- grades measured largely by short-answer standardized tests-we get into a good college. If we achieve academically in college and score well on yet another standardized test, we may get into a good law school. If we work hard in law school and get more good grades, we have access to many employment opportunities. But will we be good lawyers? ${ }^{30}$

\section{Emotional Intelligence, Lawyering, and Legal Education}

In focusing on emotional intelligence, I am not necessarily attacking the relevance or importance of criteria like a student's LSAT score or GPA in

${ }^{29}$ See Gardner, Multiple INTElligences, supra note 3, at 8-9:

If you do well in language and logic, you should do well in IQ tests and SATs, and you may well get into a prestigious college, but whether you do well once you leave is probably going to depend as much on the extent to which you possess and use the other intelligences, and it is to those that I want to give equal attention.

GolemAN, supra note 1, at 34-36:

Academic intelligence has little to do with emotional life. The brightest among us can founder on the shoals of unbridled passions and unruly impulses; people with high IQs can be stunningly poor pilots of their private lives.

[A]cademic intelligence offers virtually no preparation for the turmoil-or opportunitylife's vicissitudes bring. Yet... our schools and our culture fixate on academic abilities, ignoring emotional intelligence, a set of traits-some might call it character-that also matters immensely for our personal destiny. Emotional life is a domain that, as surely as math or reading, can be handled with greater or lesser skill, and requires its unique set of competencies.

\footnotetext{
${ }^{30}$ See Gardner, Multiple INTELligences, supra note 3, at 8-9.
} 
assessing qualifications for law school admissions. ${ }^{31}$ Nor am I suggesting that law firms disregard academic accomplishment in assessing law graduates for employment. I am asserting, however, that the skills that these indicia measure are only a subset of the skills that make for successful lawyers. ${ }^{32}$ More importantly, perhaps, the satisfaction that one derives from a career in the law may well depend on inter- and intrapersonal capacities that are independent of academic acumen. ${ }^{33}$

There is a good deal of literature documenting the personality profiles of law students and lawyers. ${ }^{34}$ The literature, based on Myers-Briggs assessments, ${ }^{35}$ suggests a personality dichotomy: lawyers tend to be thinkers rather than feelers, and those lawyers who are thinkers are more satisfied with their chosen profession than are those who are feelers. ${ }^{36}$ One problem with the dichotomy, however, is its promotion of the concept of a separation between thinking and feeling-the notion that not only are these attributes distinct, but that they are largely mutually exclusive:

A ... basic difference ... arises from the existence of two distinct and sharply contrasting ways of coming to conclusions. One way is by the use of thinking, which is a logical process, aimed at an impersonal finding. The other way is by the

${ }^{31}$ Not that these are impervious to such attack. See, e.g., Steve Demitro, Putting the LSAT to the Test: Does It Really Predict Success?, ChI. DaiLy L. Bull., Dec. 27, 1991; James C. Hathaway, The Mythical Meritocracy of Law School Admissions, 34 J. LeGal. Educ. 86 (1984); Susan Skiles, Debate Over the Value of LSAT Continues, ChI. Dally L. Bull., Feb. 7, 1992; Bruce I. Zimmer, Symposium: Legal Education in an Era of Change. The Size and Quality of the Law School Applicant Pool: 1982-1986 and Beyond, 1987 Duke L. J. 204 (1987).

${ }^{32}$ See Watson, supra note 12 , at 117 (noting importance to lawyering of ability to relate to people and ethical and professional skills).

${ }^{33}$ This may be even more true for women. See, e.g., LANi Guinier, Michelle Fine \& Jane Balin, Becoming Gentlemen: Women, Law School, and Institutional Change 49 (1997) (women are five times more likely than men to seek professional help for law school concerns); Daicoff, Lawyer, Know Thyself, supra note 11, at 1399-1402 (describing studies by Taber and Janoff demonstrating law school's greater psychological impact on women because of its devaluation of human relation concerns); Ann L. Iijima, Lessons Learned: Legal Education and Law Student Dysfunction, 48 J. LEGAL ED. 524, 531 (1998) ("Anecdotal evidence suggests that, while law school affects both men and women students adversely, the emotional impact on women is significantly more acute."); Salovey \& Mayer, supra note 5, at 194 ("A number of researchers have found that women are generally better in recognizing emotions in facial expressions than are men").

${ }^{34}$ Much of this literature is skillfully described in Daicoff, Lawyer, Know Thyself, supra note 11.

${ }^{35}$ The Myers-Briggs Type Indicator (MBTI) integrates Jungian theory on psychological types aiming to identify the individual's basic preferences as dichotomous in nature. David A. Cowan, An Alternative to the Dichotomous Interpretation of Jung's Psychological Functions: Developing More Sensitive Measurement Technology, 53 J. OF PERSONALITY AssessMent 459, 462 (1989).

${ }^{36}$ See Daicoff, Lawyer, Know Thyself, supra note 11, at 1361-62 (describing studies indicating that "lawyers who are more objective, rational, and logical in decision-making style were the most satisfied"); id. at 1365-66, 1392-93 (describing several studies that law students and lawyers differ from general population by "marked preference for Thinking over Feeling" and that this "has remained a constant over time, independent of gender influences."). See also Deborah Cassens Moss, Lawyer Personality, February 1991 ABA Journal 34 ("The truly happy lawyers tend to be logical, dispassionate problem solvers."). I have written elsewhere about the relevance of attorney attributes in explaining lawyers' antipathy toward crediting psychic influences in how they practice law. Silver, supra note *, at 279-80. 
use of feeling, which is the process of appreciation, equally reasonable in its fashion, bestowing on things a personal, subjective value. ${ }^{37}$

Salovey and Mayer noted the two traditions of Western thought, one viewing emotions as disruptive and maladaptive, ${ }^{38}$ the other perceiving emotions as motivating factors for purposeful activity. ${ }^{39}$ Furthermore, recent work of Antonio Damasio provided scientific evidence that not only are thinking and feeling not mutually exclusive, but that rational decision making is dependent on emotional input. $^{40}$

I (and others) have written elsewhere about lawyers' resistance to acknowledging the power of their emotional lives. The personality profile of the typical law student; the emphasis on rational, analytical discourse and the Socratic method in law school; the talents that are ratified and rewarded in practice: all contribute to the devaluation and denial of emotional processes and influences. ${ }^{41}$

${ }^{37}$ Paul Van R. Miller, Personality Differences and Student Survival in Law School, 19 J. LEGAL, EDuc. 460, 463 (1967) (quoting Isabel B. Myers, Manual (1962), The Myers-Briggs Type Indicator (Princeton, N.J.: Educational Testing Service, 1962), 52).

${ }^{38}$ Salovey and Mayer start with Publilius Syrus' 1st century B.C. assertion of "Rule your feelings, lest your feelings rule you" to the 1940 edition of the psychologist R.S. Woodworth, who argued that "a scale to measure IQ should contain tests demonstrating not being afraid, angry, grieved, or inquisitive over things that arouse the emotions of younger children." Salovey \& Mayer, supra note 5 at 185 (citations omitted).

${ }^{39}$ Id. at 186 (citations omitted).

${ }^{40}$ Antonto R. Damasio, Descartes' Error: Emotion, Reason, and the Human Brain (1994).

${ }^{41}$ See Silver, supra note *, at 279-81; GUINIER ET AL., supra note 33, at 50-53 (Socratic method teaches students to devalue their emotional responses); Janeen Kerper, Creative Problem Solving vs. the Case Method: A Marvelous Adventure in Which Winnie-the-Pooh Meets Mrs. Palsgraf, 34 CAL. W. L. REv. 351, 353-54 (1998) (In traditional legal education "[a]dvocacy and assertiveness are seen as important skills. Emotion is consciously repressed in favor of a detached analysis."). Guinier, Fine, and Balin noted the particular stress this creates for women and students of color:

Third-year White woman: I feel that [compassion] is something that is eradicated in law school. This notion that we can present things as though, like law, it's a self-contained unit, it's a sphere that we can look down upon as though we were astronauts that can look down on the earth. The whole idea that these things are neutral and that a neutral outcome results just eliminates any notion of compassion because professors sort of play on that, "Oh, well you feel sorry for these people. Oh well, that's too bad. Oh, well the law says, X." We are really taught that compassion is a bad thing.

$$
\text { ... }
$$

[Latino man:] The one thing bad about the way I argue now is that I think it's a little bit less passionately. I've been taught [here] that emotion in an argument is a minus and in my culture emotion in an argument is a plus. And here whenever you present an emotional side of an argument-which I think is just as valid as many other arguments-you know, about the abortion issue. You know, how a woman feels about having to have a baby--and I mean why isn't that any more legitimate than endless arguments about the constitutional right to privacy? I don't think one really should take precedence over the other. And I think it's instilled in you that if you make an emotional argument then it's wrong.

GUINER ET AL. at 52-53. My own experience supports these observations. For example, each semester toward the end of the Professional Responsibility class I teach, I survey the students as to their expectations, hopes, and fears about the practice of law. In Spring 1999, in response to the question "What concerns you most about the practice of law?" one student wrote: "Keeping the professional and emotional side separate." Also, in Larry Dubin's powerful video, WHAT WENT Wrong? Conversations With Disciplined Lawyers, one of the interviewed lawyers complained 
However, deficiency in intrapersonal intelligence takes its toll, leading to disproportionately high levels of stress, substance abuse, and depression among lawyers. ${ }^{42}$ Deficits in interpersonal intelligence adversely affect attorneys' capacity to empathize with their clients, counsel them, and gain their trust. ${ }^{43}$ The inability to understand the emotional undercurrents among their adversaries is also likely to limit their skill at negotiating and resolving controversies.

\section{A. Popular Culture, Psychology, and Legal Education}

You treat a disease, you win, you lose. You treat a person, I guarantee you, you win no matter what the outcome.-Patch Adams ${ }^{44}$

Two recent popular films and a play have influenced my musings on emotional intelligence and the study and practice of law. Two were actually about the medical profession: Margaret Edson's Pulitzer Prize winning play Wit, about the last months of a woman's struggle with advanced metastatic ovarian cancer, ${ }^{45}$ and Patch Adams, the 1999 film starring Robin Williams. ${ }^{46}$ The second film, based on the 1946 Terence Rattigan play, The Winslow Boy, ${ }^{47}$ was the only one of the three to portray a lawyer, the highly reputed British barrister, Sir Robert Morton.

1. Wit. Dr. Vivian Bearing, the protagonist in Wit, is a distinguished professor and brilliant scholar of the Holy Sonnets of the 17th-century poet, John Donne. Vivian has always navigated through life by her sharp intellect and brilliant academic achievements. ${ }^{48}$ Language - the clever, erudite use of wordshas helped keep her at arm's length from her emotions ${ }^{49}$ as well as from the

that law school failed to prepare you for what he called "the plumbing" of law. He specifically complained about the lack of preparation for dealing with clients' emotions.

${ }^{42}$ See Silver, supra note *, at $281-82$.

${ }^{43}$ See Steven Keeva, Beyond the Words: Understanding What Your Client is Really Saying Makes for Successful Lawyering, A.B.A. J. 60-63 (Jan. 1999) (discussing importance of listening skills in lawyering); Victoria J. Koch, The Specter of Death, A.B.A. J. $82-83$ (Nov. 1998) (discussing importance of empathic skills in counseling bereaved clients).

${ }^{44}$ Robin Williams as Hunter (Patch) Adams in Patch Adams (Universal Studios 1999).

${ }^{45}$ EDson, supra note 7.

${ }^{46}$ The film is based on a true story. See, infra note 66.

${ }^{47}$ Terence RatTigan, The Winslow Boy (1946). The story was largely unchanged in the film's re-creation, and I have used the published play for discussion in this article.

${ }^{48}$ See, e.g., EDSon, supra note 7 , at 74.

${ }^{49}$ See, e.g., id. at 5 :

VIVIAN (to the audience): There is some debate as to the correct response to this salutation [How are you feeling today?]. Should one reply "I feel good," using feel as a copulative to link the subject, $l$, to its subjective complement, good; or "I feel well," modifying with an adverb the subject's state of being?

I don't know. I am a professor of seventeenth-century poetry, specializing in the Holy Sonnets of John Donne.

See also id. at 43-44:

VIVIAN: I want to know what the doctors mean when they ... anatomize me. And I will grant that in this particular field of endeavor they possess a more potent arsenal of terminology than I. My only defense is the acquisition of vocabulary. 
emotions of others. ${ }^{50}$ In much of the play, she demonstrates little or no capacity to give or receive human kindness. ${ }^{51}$ For the first time in her life, her brilliant mind, her wit, fails her in her struggle against stage four metastatic ovarian cancer, an almost always deadly disease. ${ }^{52}$ Her response to the news of her cancer is to attack it as she would a difficult text. ${ }^{53}$ She fights cancer with the same intellectual tools on which she has always relied. On medical advice, she pragmatically chooses to participate in an aggressive experimental treatment program. ${ }^{54}$ The cancer plays by different rules, however.

Vivian's only current significant relationships are with the three people who comprise her health care team: her primary care nurse, Susie Monahan; the chief of medical oncology of University Hospital, Harvey Kelekian ${ }^{55}$; and a young clinical fellow, Jason Posner. Not surprisingly, the only one of the three with a bedside manner is the nurse. Susie repeatedly defends Vivian's humanity against the dispassionate objectives of the medical researchers, scientists whose fascination with cancer and obsession with their own contributions to the body of research seeking to find its cure, are accompanied by a loss of perspective on their patient's painful journey. ${ }^{56}$ ${ }^{50}$ See,

${ }^{50}$ See, e.g., id. at 12 ("I know for a fact that I am tough. A demanding professor. Uncompro-

${ }^{51}$ See, e.g., id. at 34 (stage direction states that Vivian is uncomfortable with the nurse's human kindness); id. at 63 (Vivian remembering having denied a student whose grandmother has died an extension on a paper).

${ }_{52}$ As Vivian remarks to the audience, "There is no stage five." Id. at 12.

53"Must get some books, articles. Assemble a bibliography. Is anyone doing research on cancer?" Id. at $8-9$.

${ }^{54}$ Id. at $7-12$.

${ }^{5}$ In the beginning of the play, Vivian and Dr. Kelekian commiserate with each other about the burdens they share in their quest to mold young minds. Id. at 10:

VIVIAN: "Thoroughness"-I always tell my students, but they are constitutionally averse to painstaking work.

KELEKIAN: Yours too.

VIVIAN: Oh, it's worse every year.

KELEKIAN: And this is not dermatology, it's medical oncology, for Chrissake.

VIVIAN: My students read through a text once-once!- and think it's time for a break.

KELEKIAN: Mine are blind.

VIVIAN: Well, mine are deaf.

${ }^{56} I d$. at 68 (Susie discussing with Vivian whether Vivian wants to opt for a "Do Not Resuscitate" (DNR) order, discussing inclinations of Kelekian \& Jason in this regard):

SUSIE: Well, they like to save lives. So anything's okay, as long as life continues. It doesn't matter if you're hooked up to a million machines. Kelekian is a great researcher and everything. And the fellows, like Jason, they're really smart. It's really an honor for them to work with him. But they always ... want to know more things.

VIVIAN: I always want to know more things. I'm a scholar. Or I was when I had shoes, when I had eyebrows.

Id. at 82 (when Jason discovers that Vivian's heart has stopped, and he calls for "Code Blue" to revive her, even though Vivian had requested, and Dr. Kelekian had signed, a DNR order the preceding day):

SUSIE:

JASON:

SUSIE:

WHAT ARE YOU DOING? A GODDAMN CODE. GET OVER HERE! She's DNR. 
Jason, the young researcher, who had taken Vivian's course on 17th-century poetry as an undergraduate, ${ }^{57}$ explains to her why he chose to go into cancer research. $^{58}$ Even as her disease progresses, Vivian clearly relates to Jason's fascination with cancer. She admires his intellectualization and objectification of the disease as a wonderful, enigmatic puzzle to be conquered. ${ }^{59}$ At the same time, however, she begins to acknowledge her own emotional needs and fears, fears which Jason mistakes for mental confusion. ${ }^{60}$ As her strength diminishes and her pain increases, Vivian begins to respond to the gentle human kindness of the nurse. $^{61}$

VIVIAN: Now is not the time for verbal swordplay, ... for wit.

And nothing would be worse than a detailed scholarly analysis.

JASON: She's research!

${ }^{57}$ Vivian asks if Jason was an English major:

JASON: No. Biochemistry. But you can't get into medical school unless you're well rounded. And I made a bet with myself that I could get an A in the three hardest courses on campus. (He got an $\mathrm{A}-$ ).

Id. at $21-22$.

${ }^{58} I d$. at $56-57$. As a researcher, Jason has little tolerance of requirements that he develop clinical skills such as remembering to say hello and goodbye to his patients. See, e.g., id. at 40, 47, 57.

JASON: - [T]here's a whole course on [bedside manner] in med school. It's required. Colossal waste of time for researchers.

Id. at 55 .

${ }^{59} 1 d$. at 56 :

JASON: Cancer is ... (Searching.)

VIVIAN: (Helping.) Awesome.

JASON: (Pause.) Yeah, that's right. It is. It is awesome. How does it do it? . . Even on the protistic level the normal cell-cell interactions are so subtle they'll take your breath away... It's perfect. So what's up with the cancer cells? Smartest guys in the world, with the best labs, funding - they don't know what to make of it.

Id. at 77:

JASON: When it comes right down to it, research is just trying to quantify the complications of the puzzle.

${ }^{60} I d$. at 58 :

VIVIAN: And what do you say when a patient is ... apprehensive, ... frightened.

JASON: Of who?

VIVIAN: $\quad$ I just .... never mind.

JASON: Professor Bearing, who is the president of the United States?

(When Jason leaves:)

VIVIAN: So. The young doctor, like the senior scholar, prefers research to humanity. At the same time the senior scholar, in her pathetic state as a simpering victim, wishes the young doctor would take more interest in personal contact. Now I suppose we shall see, through a series of flashbacks, how the senior scholar ruthlessly denied her simpering students the touch of human kindness she now seeks. Id. at 58-59.

${ }^{61}$ Id. at $64-70$. 
Erudition. Interpretation. Complication.

(Slowly.) Now is a time for simplicity. Now is a time for, dare I say it, kindness.

(Searchingly.) I thought being extremely smart would take care of it. But I see that I have been found out. Ooohhh .... ${ }^{62}$

Were she to choose again, Vivian might well still have decided to participate in the experimental treatment regime. She likely would still have wanted the best and the brightest minds on her side in her war against cancer. Would that she would not have had to choose between the best and the brightest, and the kindest and most understanding.

A recent article quoting Dr. Larry Norton, chief oncologist at Memorial Sloane-Kettering, highlighted both the possibility and the rarity of this kind of care from a medical doctor:

Look, it's never true that you can't do something for a patient.... You can alleviate suffering, help them help their family, give them a sense of purpose. To take care of someone's body and not their soul is to not take care of them fully. Sometimes the soul is right there on the surface and easily touched. Sometimes it's very deep. But your skill as a physician is about your skill to get in there and heal whatever is broken. ${ }^{63}$

2. Patch Adams. Patch Adams and Larry Norton share an all too uncommon concern with the humanity of their patients. In the beginning of the film, Patch appears to be an unusual candidate for a medical degree. After committing himself to a mental hospital as a suicide risk, he begins to use play, laughter, and wit to help other troubled patients and, through so doing, finds his calling. He determines to go to medical school and become a doctor-"to help people."

Patch is an outstanding student academically, but he is an iconoclast who challenges authority and continuously breaks rules, such as those that prohibit medical students from interacting with patients during their first 2 years. Patch defies edicts to the contrary and continues to visit, offer compassion, and entertain with antics that bring laughter and joy into the lives of medical patients battling terminal illnesses. "What's the difference between a doctor and a scientist?" he asks his friend and fellow medical student, Truman. "People ... . You have to learn to treat the patient as well as the disease. We have to dive into people, wade into the sea of humanity."

However, Patch must contend with the humorless Dean Wolcott, who has a rather different vision than Patch. At their first one-on-one meeting, after he catches Patch entertaining the children in the pediatric ward, Wolcott tells him

${ }^{62} I d$. at $69-70$.

${ }^{63}$ Jan Hoffman, Public Lives: A Cancer Doctor Mindful of Body and Soul, N.Y. TIMEs, May 28, 1999, at B2 col. 4 (emphasis added). The reporter asked Dr. Norton how he deals with patient loss:

I could take care of someone for many years and feel as close to her as two people can be. ... She dies. The family has an expected period of mourning. But the physician has to get up the next day and go to work. Nobody allows us our mourning. They want us to be as intimately involved as a loved one and then, that's it, we're out. But I am sure I'm closer in some ways to the women who died than the husbands who remarried and got on with their lives. 
that he has heard that Patch has a real passion to be a doctor. "The truth of it is, Hunter, passion doesn't make doctors. I make doctors. Understood?" The next time Wolcott catches him in the hospital and reminds him that Patch was not to see patients until the third year, Patch replies, "I'm just visiting friends, sir."

"Why are you here?" Wolcott retorts. "If you want to be a clown go join the circus. Patients don't need to be entertained. They don't need a friend. They need a doctor." Ultimately, Patch's antics provoke Wolcott to dismiss him from school. Patch asks, "Why am I such a threat to you, sir?" Wolcott replies, "Because what you want is for us to get down on the same level as our patients. To destroy objectivity. All to uphold some idealistic buddy system that will allow you to work through your own feelings of inadequacy." Patch goes over Wolcott's head and persuades Dean Anderson (who admits thinking Wolcott a pain in the posterior) to reverse the dismissal. However, Patch is warned to stay out of trouble, which apparently he does until his third year.

Shortly before he is to graduate, Patch again receives a letter of dismissal from Dean Wolcott. Patch storms into Wolcott's office demanding an explanation. Wolcott tells him the following:
"You don't fit into our standards and codes. You make the patients and everyone else around you uncomfortable."
"I make you uncomfortable!"
"The reality is, you are not cut out to be a physician ..."

Patch grabs his file from the office. Along with documentation of his extremely high grade point average, Patch finds a note that states "Excessive happiness."

Patch appeals and there is a dramatic hearing, ${ }^{64}$ at which Patch addresses the panel of physicians sitting in judgment of him: "If we're going to fight a disease, let's fight one of the most terrible diseases of all: indifference.... I've heard people lecture on transference and professional distance. Transference is inevitable, Sir. Every human being has an impact on another. Why don't we want that in a patient-doctor relationship?"65 Patch wins and becomes a doctor. ${ }^{66}$

${ }^{64} \mathrm{Patch}$ is charged with practicing medicine without a license. He and his friends had been operating a sort of free "clinic" offering care (physical and emotional) to anyone who asked.

${ }^{65}$ In an interchange early in the film with Corin, a serious classmate who becomes Patch's love interest, Patch asks her why patients are referred to by their disease and not their name. She replies, "Well it's certainly not to be mean; it's to prevent transference." Patch responds, "And why is that bad? What if a doctor becomes emotionally involved with a patient? What is wrong with that? Does the doctor explode?"

${ }^{66}$ Listening to the complaints of local people about the health care system, Patch has a brainstorm about opening a free hospital, "the first fun hospital in the world. We'll use humor to heal pain and suffering. Doctors will work side by side with patients as peers. Where joy is a way of life; where learning is the highest aim, where love is the ultimate goal." Text on the screen at the end of the film says the following:

During the next 12 years, Patch Adams opened a home-based medical practice and treated more than 15,000 people without payment, malpractice insurance, or formal facilities. He purchased the 105 acres in West Virginia, and construction of the Gesundheit Hospital is currently underway. To date, a waiting list of over 1,000 physicians have offered to leave their current practice and join in Patch's cause. 
The relevance of Wit and Patch Adams to the issues I have identified with regard to both legal education and the practice of law are not difficult to discern. Although medical school training in "bedside manner" is increasing, it is still in its infancy and, where it exists, tends to be marginalized in the curriculum. ${ }^{67}$ The similarities between medical education and legal education in their neglect of emotional skills training is striking. ${ }^{68}$

3. The Winslow Boy. The plot of The Winslow Boy is quite simple. It is shortly before World War I, and a young boy, Ronnie, has returned from the military academy to his upper middle class home in South Kensington, London. ${ }^{69}$ He has been expelled for stealing and cashing a postal order belonging to another cadet. ${ }^{70}$ His stern but loving father, Arthur Winslow, believes his son's protestations of innocence and thus begins a campaign to clear Ronnie's name that comes at great financial and emotional cost to his entire family. ${ }^{71}$ In pursuit of justice, Mr. Winslow enlists the assistance of Sir Robert Morton, a sort of British Clarence Darrow, reputed to be the best barrister in all of England. ${ }^{72}$ Catherine (Kate), Ronnie's older sister, a feminist and activist for social justice, holds contempt for what she perceives to be Sir Robert's reactionary political agenda. ${ }^{73}$

When we first meet him in Act II, Sir Robert Morton would appear to be the paradigmatic lawyer who represses his feelings, whose emotional displays are no more than carefully contrived theatrics for gaining adversarial advantage. One such example is his interview of Ronnie before deciding whether "to accept the brief." 74 While Ronnie persists in maintaining his innocence, Sir Robert bril-

${ }^{67}$ See Abigail Zuger, When the Doctor and Patient Need Couple's Therapy, N.Y. TimEs, Mar. 31,1998 , at F4, col. 1 ("The current system of medical education leaves learning how to communicate well with patients entirely up to chance" quoting Dr. Dennis Novack, professor of medicine at the Medical College of Pennsylvania-Hahnemann School of Medicine in Philadelphia). But see Brett Levinson, Letter to the Editor, N.Y. TIMES, Jan. 19, 1999, at F5, col. 1 (describing empathy training at University of Maryland School of Medicine).

${ }^{68}$ See Goleman, supra note 1 , at 165 :

By now a scientific case can be made that there is a margin of medical effectiveness, both in prevention and treatment, that can be gained by treating people's emotional state along with their medical condition. ... [L]ooking at the data from hundreds and hundreds of cases, there is on average enough increment of medical benefit to suggest that an emotional intervention should be a standard part of medical care for the range of serious disease.

[T] here is the added medical value of an empathic physician or nurse, attuned to patients, able to listen and be heard. This means fostering "relationship-centered care," recognizing that the relationship between physician and patient is itself a factor of significance. Such relationships would be fostered more readily if medical education included some basic tools of emotional intelligence, especially self-awareness and the arts of empathy and listening.

Id. at 183. Goleman advocated for mainstreaming emotional intelligence in medical school education. Id. at 185. See also Howard F. Stein, The Psycho-Dynamics of Medical Practice: UnconSCIOUS FACTORS IN PATIENT CARE 1 (1985) ("Unconscious resistance to acknowledging subjective involvement within medicine is as pervasive in clinical practice as it is unaddressed in medical education, for medicine relies heavily on objectivity. Ironically, objectivity is itself a subjective claim."); Silver, supra note *, at 305.

${ }^{69}$ Ratrigan, supra note 8 , at 1 .

${ }^{70}$ Id. at 20,30 .

${ }^{71}$ Id. at $32-33$.

${ }^{72} I d$. at 52 .

${ }^{73}$ Id. at $52-53$.

${ }^{74}$ See BYRNES's LAW DICTIONARY 137 (1991) (“'AA] brief is a document containing the materials 
liantly cross-examines the boy, nearly devastating Ronnie and his family with the inconsistencies and unlikely coincidences of Ronnie's story-at the end of which, Sir Robert, too, is convinced of Ronnie's innocence and agrees to represent him. ${ }^{75}$

In Act III, Sir Robert demonstrates his skillful use of theatrics as trial tactics. The following exchange occurs between Kate and her father after Kate describes Sir Robert's reaction to the refusal of the First Lord to grant a trial:

Arthur: ... But didn't Sir Robert make any protest when the First Lord refused a trial?

Catherine: Not a verbal protest: something far more spectacular and dramatic. He uncoiled those long legs of his-he'd had his feet on the Treasury table and his hat over his eyes, during most of the First Lord's speech-and got up very deliberately. Then he glared at the First Lord, threw a whole bundle of notes on the floor, and stalked out of the House. It made a magnificent effect. If I hadn't known I could have sworn he was genuinely indignant-

A.: $\quad$ Of course he was genuinely indignant. So would any man of feeling be--

C.: $\quad$ Sir Robert, Father dear, is not a man of feeling. I don't think any emotion at all can stir that fishy heart-

A.: $\quad$ Except perhaps a single-minded love of justice.

C.: Nonsense. A single-minded love of Sir Robert Morton. ${ }^{76}$

In Act IV, the Attorney General, finally convinced of Ronnie's innocence, dismisses all charges against him. ${ }^{77}$ Catherine hears first from the housekeeper that Sir Robert had tears running down his face when the decision was announced in court. ${ }^{78}$ Shortly after, Sir Robert arrives at the Winslow home fully composed to report the happy development. ${ }^{79}$ Kate, who has not quite recovered from news delivered to her earlier by the family's solicitor to the effect that Sir Robert turned down an appointment as Chief Justice to continue with the Winslow case, questions Sir Robert about his tears:

Sir Robert: My dear Miss Winslow, are you cross-examining me?

Catherine: On this point, yes. Why are you so ashamed of your emotions?

SR: $\quad$ Because, as a lawyer, I must necessarily distrust them.

C: $\quad$ Why?

SR: $\quad$ To fight a case on emotional grounds is the surest way I know of losing it. Emotions muddy the issue. Cold, clear logic_-and buckets of it-should be the lawyer's only equipment.

C: $\quad$ Was it cold clear logic that made you weep today at the verdict?

SR: $\quad$ Your maid, of course, told you that? It doesn't matter. It will be in the papers tomorrow anyway. (Fiercely) Very well, then, young lady, if you must have it, here it is, in all its highfalutin repulsiveness. I wept today because Right had been done.

or instructions furnished by a solicitor to a barrister to enable him to represent the client. ... The brief is the authority of the barrister to appear for the client ...").

${ }^{75}$ Id. at $59-69$.

${ }^{76}$ Id. at $79-80$.

${ }^{77}$ Id. at 120 .

${ }^{78} \mathrm{Id}$. at 118 .

${ }^{79} \mathrm{Id}$. at $119-20$. 
C: $\quad$ Not justice?

SR: $\quad$ No. Not justice. Right. It is easy to do justice-very hard to do right. Unfortunately, while the appeal of justice is intellectual, the appeal of right appears for some odd reason to induce tears in court. That is my answer and my excuse. And now, may I leave the witness box ? $^{80}$

4. Personality attributes, lawyers, and law students. I thought about Sir Robert on reading Susan Daicoff's article about the relationship between attorney attributes and problems with the legal profession. ${ }^{81}$ Daicoff identified a "tripartite crisis" in the legal profession, claiming that the problems fall into three interdependent general categories: professionalism, public opinion, and lawyer dissatisfaction. ${ }^{82}$ She described empirical studies evidencing attorney dissatisfaction with the practice of law and the corresponding high levels of alcoholism, drug abuse, depression, and drop-out among attorneys. ${ }^{83}$ She surveyed proffered explanations for the burgeoning of these problems over the past decade ${ }^{84}$ and then canvassed a variety of proposed solutions. ${ }^{85}$ However, what is most original and disquieting in this piece is Daicoff's discussion of the weaknesses and self-contradictions of these proposals. For example, she suggested that for attorneys to become "Problem-Solvers Instead of Conflict-Conflagrators," -two of the solutions suggested in the literature to decrease public dissatisfaction and increase attorney satisfaction and civility--would require a change in attorney attributes and the types of persons who are attracted to study law and become lawyers. ${ }^{88}$ Moreover, it might in fact be maladaptive for, at the least, "the current adversarial style of practice": 89

Not only is personality change difficult to achieve, but a more interesting and poignant question may be why individuals who are so lacking in interpersonal skills self-select into law school in the first place. Law appears to attract individuals who are more rational, logical, and analytical than individuals in other careers. Legal education appears to amplify these tendencies. The practice of law, then, may continue to encourage individuals to excise their emotions, interpersonal caring, and sensitivity from their daily work so that they may function in their roles as attorneys without experiencing undue psychic conflict.

Adopting such a perspective may be adaptive to the practice of law. ${ }^{90}$

So far, Daicoff's empirical observations seem consistent with Sir Robert's

${ }^{80} I d$. at 124 .

${ }^{81}$ Daicoff, Asking Leopards to Change Their Spots, supra note 11. See also Daicoff, Lawyer, Know Thyself, supra note 11.

${ }^{82}$ Daicoff, Asking Leopards to Change Their Spots, supra note 11, at 547, 549.

${ }^{83} I d$. at $549,555-57$.

${ }^{84} \mathrm{Id}$. at $557-66$.

${ }^{85} \mathrm{Id}$. at $566-81$

${ }^{86} \mathrm{Id}$. at 580 .

${ }^{87} \mathrm{Id}$. at $578-80$.

${ }^{88} \mathrm{Id}$. at 579.

${ }^{89} \mathrm{Id}$. at 581 .

${ }^{90} I d$. at 579-80. Daicoff recognized, however, that the attorney attributes that may be adaptive to the adversarial process "because they allow the lawyer to avoid feeling unduly emotional about his or her clients' case, may be maladaptive in the client counseling part of legal practice." Daicoff, Lawyer, Know Thyself, supra note 11, at 1412. In her contribution to this theme issue, Daicoff has 
declaration: emotions are the enemy of the advocate. But Sir Robert, perhaps, doth protest too much. Twice in the play Sir Robert hints at the toll his "role" takes. In Act III, he asks Kate for a cigarette:

Catherine: ... I thought you didn't smoke?

Sir Robert: Only occasionally-in moments of stress. ${ }^{91}$

Again, in Act IV, on returning from court to the Winslow household, Sir Robert asks for a glass of whiskey. He slumps in a chair, and Catherine notices his hand is trembling.

Catherine: Would you like me to get a doctor, Sir Robert?

Sir Robert: No, no. Certainly not. There is nothing the matter with me. Just a slight nervous reaction-that's all. Besides, I have not been feeling myself all day. I told the judge so, this morning, if you remember, but I doubt if he believed me. He thought it was a trick. What suspicious minds people have, have they not?

Now surely I could be accused of making a mountain out of a pair of molehills, but I must conclude that Rattigan deliberately chose to suggest a "nervous" side to Sir Robert, which stands in sharp contrast to the complete control he otherwise demonstrates professionally. If Daicoff and Sir Robert are right-if, in fact, certain types of law practice require the suppression of emotions ${ }^{92}$ - then this may be a quandary without an adequate solution. Perhaps such "stress" and "nervousness" and need for whiskey is a necessary cost, and one that good litigators and other advocates are destined to suffer. If the success is great and the suffering minimal, then the trade-off may well be worth it. But I doubt it. ${ }^{93}$

Daicoff not only argued that changing lawyers' personality attributes might be difficult $^{94}$; she suggested that it might in fact be detrimental to their well-being. ${ }^{95}$ Some of her conclusions are rather unsettling:

suggested that the therapeutic jurisprudence-preventive lawyering model is especially well-suited for lawyers with atypical attributes. Daicoff, supra note 10, at 835,843 .

${ }^{91}$ Ratrigan, supra note 8 , at 85.

${ }^{92}$ Daicoff, Asking Leopards to Change Their Spots, supra note 11, at 580, 584.

The personality type least frequently found in law school and most frequently found in those dropping out was described as "concerned chiefly with people, ... . values harmonious human contacts,... friendly, tactful, sympathetic, and loyal, who is warmed by approval and bothered by indifference and who tends to idealize what he admires.

(citing Paul Van R. Miller, Personality Differences and Student Survival in Law School, 19 J. LeGAL EDuc. 460, 466 (1967).) Id. at 585-86. It is interesting to note that Van R. Miller's article was published only 1 year before Watson's Cincinnati piece, Watson, supra, note 12, discussed infra at notes 104-134 and accompanying text.

${ }^{93}$ The studies reported by Daicoff indicate, however, that whatever the success, the cost is great. "An incidence of substance abuse and psychological distress among lawyers that is almost twice that of the general population simply is not tolerable." Daicoff, Asking Leopards to Change Their Spots, supra note 11, at 595.

${ }^{94}$ Id. at $589-90 ; 594-95$.

${ }^{95}$ Id. at 588:

[R]esearch suggests that potentially detrimental effects arise from asking lawyers to become more caring, interpersonally sensitive, altruistic, and Feeling-oriented. Changing to embrace 
If the distressed lawyers are those that do not have the traits characteristic of most lawyers, e.g., they are Feelers, sociable, people-oriented, emotional individuals who espouse an ethic of care and cannot divorce their values from their work, or who, if they engage in unprofessional or unethical behavior, do so because of unresolved inner moral conflicts, lack of moral compass, confusion, or psychological distress including substance abuse, this author opines that most of the proposed solutions to the tripartite crisis miss the mark. Instead, this subset of lawyers needs to develop more of the common attorney attributes in order to raise career satisfaction and resolve conflicts or find alternative ways to practice law. ${ }^{96}$

Daicoff ultimately proposed further empirical study to identify the attributes of distressed attorneys in order to determine what, if anything, needs changing. ${ }^{97}$ I agree that further study is warranted. However, I worry what we would make of results concluding that those with less aggressive and competitive attributes are more distressed than those with more typical attorney attributes. ${ }^{98}$ Given the myriad roles lawyers play and serve in our society, it is a terrible mistake to try and conform all lawyers to a single aggressive, adversarial mode. Traditional legal education reinforces the adversarial mode of lawyering and is more or less well suited to training those with an inclination toward aggressiveness and competition. Such a mold, however, ill serves problem solvers and counselors. ${ }^{99}$ Lawyers and teachers committed to practice with an ethic of care, ${ }^{100}$ or preventive

these attributes might enhance professionalism and public opinion of lawyers, but such a change might actually increase lawyer psychological distress and career dissatisfaction.

${ }^{96} I d$. at 592 (emphasis added). Daicoff suggested what such "alternative ways to practice law" might be. See Daicoff, supra note 10, at 833-35.

${ }^{97}$ Daicoff, Asking Leopards to Change Their Spots, supra note 11, at 593, 595.

${ }^{98}$ See, e.g., GUFNIER ET AL, supra note 33, at 29:

Although some have said in response to our data [demonstrating weaker academic performance, greater distress and alienation among women law students at University of Pennsylvania Law School] that perhaps most women are not well suited to law school or should simply learn to adapt better to its rigors, we are inclined to believe that it is law school-not the women-that should change. Indeed, changes to the existing structure of the law school might improve the quality of legal education for all students.

${ }^{99} I d$. at 15-16:

[N]ot all problems can be solved through quick thinking or aggressive questioning. Not all problems belong in court. Not all problems lend themselves to litigation. Often lawyers work as members of teams representing large organizations in multiparty transactions or disputes and only rarely go to court. The lawyer as aggressive litigator representing a single client may be outmoded in terms of what most lawyers actually do, and this paradigm may be dysfunctional in terms of "the collection of competencies" lawyers need to possess in order to do their jobs well.

${ }^{100}$ Some writers perceive a conflict between an ethic of care and a rights-justice perspective. See, e.g., Daicoff, Lawyer, Know Thyself, supra note 11, at 1400-02 (describing Sandra Janoff's 1989 study concluding that although most women arrive at law school with an "ethic of care," it is beaten out of them by the rights orientation of traditional legal education). The biggest problem in practice, I believe, is not with crusaders for justice, but rather with that segment of the bar that perceives law as a competitive business. See, e.g., id. at 1344, 1424-25 (decline in professionalism in part attributed to law becoming a business rather than a profession). If the ordinary practitioner- 
lawyering, or therapeutic jurisprudence, would similarly be poorly served. ${ }^{101}$ Not only is there room in the profession for thinkers and feelers, we should aspire to cultivate thinking and feeling. Legal education must be responsive to all appropriate varieties and styles of lawyering by helping cultivate emotional as well as analytical skills. ${ }^{102}$

5. A psychiatrist's look at legal education. It is interesting to contrast Daicoff's largely empirical approach to analyzing the profession's problems with Andrew Watson's more anecdotal and personal critique of legal education, written 30 years earlier, from his unique perspective as a psychiatrist on a law faculty. ${ }^{103}$ Watson's article (which grew out of a series of lectures he gave at the University of Cincinnati College of Law in 1967) ${ }^{104}$ was written at a time when legal education - and especially legal education at the institutions with which he was most familiar $^{105}$ - serviced a rather homogeneous audience. In the $1960 \mathrm{~s}$, women were beginning to trickle into law schools, and many law students had fathers and other relatives who were lawyers. ${ }^{106}$ Yet lawyer-or at least law studentdissatisfaction and alienation was widespread, and Watson recommended a variety of reforms to legal education to address the sources of these problems. Of special interest is his psychoanalytic take on why traditional legal education caused such discontent.

Noting that few law students would have had contact with the behavioral sciences prior to law school, ${ }^{107}$ Watson commented on the tendency among law students and lawyers to intellectualize most situations, including those that the average person - the reasonable person-would expect to have more emotional content. $^{108}$ This tendency is then exacerbated by legal education, which not only does not develop the personal skills needed to relate to their clients and their clients' problems, ${ }^{109}$ but by use of little other than the case method alienates

the kind of lawyer that the vast majority of our students become-can be sensitized to the importance of caring, that would be a triumph.

${ }^{101}$ See, e.g., Daicoff, supra note 10, at 826-7; Silver, supra note *, at 292-5.

${ }^{102}$ See GUINIER ET AL., supra note 33, at 69:

Our view is that the critique many female law students present gives us an occasion to reexamine traditional assumptions about lawyering for all. This reexamination is timely in light of the changing character of the legal profession and presents an opportunity to reconsider the value of the dominant pedagogy and accompanying emphasis on adversarialism that presently permeate legal education.

${ }^{103}$ See Watson, supra note 12.

${ }^{104}$ Id. at 93, n. *.

${ }^{105}$ Watson taught first at the University of Pennsylvania Law School before joining the faculty of the University of Michigan Law School, where he held a joint appointment with the Medical School. Andrew S. Watson, The Law and Behavioral Science Project at the University of Pennsylvania: A Psychiatrist on the Law Faculty, 11 J. LEGAL EduC. 73 (1958).

${ }^{106}$ Watson, supra note 12 , at 95.

${ }^{107}$ Id. at 98 .

${ }^{108} I d$. at 113 ("The possession of impressive intellectual capacities often causes excessive use of the defense of intellectualization. This is a psychological maneuver whereby persons relate to each other and themselves primarily through ideas, even when emotional matters may be more pertinent.").

${ }^{109} I d$. at 117. 
students from the people-centered reality of everyday law practice. ${ }^{110} \mathrm{He}$ places a large measure of the blame on slavish adherence to the Socratic method:

I want to reemphasize the fact that the Socratic Method exaggerates, and in a sense, distorts the importance of intellect. I have already stressed the point that analytical skill is the hallmark of a good lawyer and a crucially important tool. However, when the Socratic Method leads to an ablation of emotional awareness, it can have a seriously distorting effect. I recall my surprise when I first heard this stated as a desired goal in the development of lawyers. A very famous lawyer, widely known for his writing on professional ethics, vigorously urged a new class of law students to eliminate their emotions in order to become what he termed a "good lawyer." While I agree completely that emotions can thoroughly disrupt a lawyer's skill, I cannot overstate the folly of attempting to eliminate them. Emotions are part and parcel of the biological reactivity of the human animal and are therefore irremovable. While they may be modified and grotesquely distorted, they are always present to influence all human behavior, even that of lawyers. The Socratic Method reinforces the false image that it is possible to get rid of emotion, and the nature of the Socratic arena in some law schools makes it sound possible to achieve this impossible goal. ${ }^{111}$

Watson noted the irony that Socrates used his method softened by more human kindness than the practice employed by law schools-at least as of 30 years ago-where students were rarely rewarded for good performance and treated generally in a way calculated (albeit perhaps not intentionally) to cause them to feel increasingly alienated from the classroom experience. ${ }^{112}$ This alienation manifested itself in a withdrawal of psychological commitment from both law school and the practice of law; rather than looking forward to law practice, many students came to doubt their career choice. Many unhappily perceived the law as divorced from the human condition. ${ }^{113}$ In order to persevere, however,

${ }^{110} I d$. at $118-19$ ("[The cases students read] reveal little, if anything at all, about the actual lawyer-client relationship, but only the conclusions which result from this process. This inevitably frustrates the avid desire of many students to find out how lawyers function, and will thus generate more resentment to deepen the internal conflicts which they ordinarily cannot express.").

Clinical courses were in their infancy as Watson was writing, and he was cautious about their utility as they then existed:

The purpose of these programs is to give the students experience with actual legal practice during the last year of their law school career. Students are assigned to corrections departments, welfare departments, to the practicing bar, and other community social agencies. My own assessment of their value as part of professional education relates directly to the amount of interpreted experience which the student encounters. Mere contact with these professional situations may do little more than stir anxiety-anxiety traced to its source and analyzed creates growth potential.

Id. at 157 .

${ }^{111}$ Id. at 124 (emphasis added).

${ }^{112} I d$. at $123-24,145-46$. Dr. Watson suggested that "[t]his method should be seriously questioned as a good teaching technique." Id. at 123 .

${ }^{113}$ Id. at 129 :

A third rationalization, which also smacks of the defense of reality, is tucked away in a student's statement that he does not feel that he will like law because it is "too cold and inhuman." While classroom discussions may lead a student to this conclusion, it is hardly accurate. There is no profession which is more involved with people and their problems than the practice of law. The fact that discussions are conducted in legal abstractions does not alter 
students adopted coping devices that inevitably decreased their empathic involvement with their clients:

It is my contention that law school education explicitly shapes the character development of law students in certain ways which are detrimental to efficient professional performance. This character adaptation is necessary in order to resolve and escape the tensions of the classroom. The principle characterological development change is to become "unemotional.". . Marked stoicism and emotional unresponsiveness may be regarded as characterological defenses against underlying emotions. Intellectual means in the form of cynicism about the human aspects of the lawyer's role may also be used to accomplish this purpose. This cynicism is a kind of characterological defense which enables a person to avoid the necessity of caring about people with its intrinsic capacity to stir up anxiety. ${ }^{114}$

Unlike Daicoff, Watson saw no inescapable impediment for reconciling lawyer attributes with emotional intelligence; he did believe, however, that at least certain aspects of legal education needed to be fundamentally altered in order to facilitate healthy integration of the rational and emotive processes.

Some of the ideas Watson proffered-use of the problem method as an alternative to the case method, for example - have been widely used for quite some time now. ${ }^{115}$ Some of his suggestions today seem outdated, even chauvinistic. ${ }^{16}$ Others, however, have a great deal of currency. These include experiential learning, ${ }^{117}$ a pervasive approach to skills training, ${ }^{18}$ acknowledgment of stress, ${ }^{119}$ cultivation of psychological insight, ${ }^{120}$ collaboration with behavioral science professionals, ${ }^{121}$ positive reinforcement, ${ }^{122}$ graduated progress reports, ${ }^{123}$ and bridge-the-gap postgraduate and continuing legal education programs. ${ }^{124}$ One of Watson's most original contributions is his suggestion that the classroom itself be a laboratory for exploring the power of the emotions and psychic life. Discussing how the Socratic method invades a student's domain of expected privacy, Watson suggested the following:

this point. However, it does require a fairly mature perceptive capacity for the student to find his way through the legal abstractions in order to discover the human elements in the cases.

${ }^{114} I d$. at 131. "The first and most important impact of current legal education techniques relates to what might be called the 'people handling skills.' Regardless of what a lawyer does, he must associate with human beings in an attempt to accurately handle their problems. Whether or not the lawyer desires this, he is plunged into the emotional melee." $I d$. at 133.

${ }^{115} \mathrm{Id}$. at $138-39$. Interestingly, and, as far as I know, nowhere adopted is his recommendation that law school start with the problem method and not introduce Socratic method until the second and third years. $I d$. at $148-49$.

${ }^{116}$ For example, Watson recommended support groups for law wives. "The young ladies, so important to the emotional well-being and often the economic well-being of their law student husbands, ordinarily get little assistance with the difficult burdens they must carry." Id. at 147.

${ }^{117} I d$. at $144-45$.

${ }^{118} \mathrm{Id}$. at 140,152

${ }^{119} \mathrm{Id}$. at 146 .

${ }^{120} I d$. at $150-52$.

${ }^{121}$ Id. at $161-62$.

${ }^{122} I d$. at $145-46$.

${ }^{123} \mathrm{Id}$. at 160 .

${ }^{124} I d$. at 163 . 
The Socratic Method of teaching, so commonly and profitably used in law schools, would surely not permit professorial abstention from such intrusions into the student's privacy .... The methods which I propose are different in as much as they acknowledge the invasion and proceed to delineate and deal with the consequences. For example, a student may became [sic] flushed and stir restlessly in his chair when he feels that a question is a threat to his competence. My technique will acknowledge these visible reactions in order that the student can recognize and begin to deal with his feelings about the invasion. The class will progressively begin to accept the fact that the teaching process stirs inner emotions although we never specifically identify the causes of a particular student's form of response. The teacher must also show willingness to acknowledge openly his responsibility for the feelings he arouses. ${ }^{125}$

This technique--one that likely would be rather unsettling to the majority of academics today $^{126}$ - has multiple goals. First, it makes explicit what the vast majority of students are likely feeling, that the method used in the classroom stirs up a variety of uncomfortable feelings. Each individual student's reaction may be validated simply by knowing not only that many, perhaps most, ${ }^{127}$ classmates are having a similar reaction (in itself an important, empowering realization), but that the teacher knows this is happening and it is an expected part of the dynamic. Second, it validates the experience that the students will one day have as lawyers, where they will be confronted with the reality of their clients' emotional lives, as well as their own. They learn that in order to render competent representation, lawyers must both acknowledge and address these feelings. ${ }^{128}$ This, of course, does not mean that lawyers so identify with their clients that their judgment become clouded by taking on the clients' feelings. Lawyers must learn to keep the appropriate distance: not so far that they are unable to empathize; not so close that they become incapacitated. Watson noted an anonymous source's apt description of human relations:

This situation is reminiscent of the philosopher's observation that human relationships may be compared to those of porcupines in cold weather-they must get close enough to stay warm, but not so close as to be pricked. This is not a bad description for lawyer and client relationships. ${ }^{129}$

Watson used problem-based exercises in order to place students-to the extent possible through "practice problems"--in the types of situations in which they could expect to find themselves as lawyers representing clients. Although

\footnotetext{
${ }^{125} \mathrm{Id}$. at 149.

${ }^{126}$ Even today I would wager that the majority of academics are resistant to acknowledging their own feelings.

${ }^{127}$ Watson noted that many students adapted relatively easily to the Socratic technique "and it has always been exciting to me to watch their development. Good students also develop the capacity to stand the pressure of the adversary situation, and I fully agree with those who see the classroom situation as a means for developing this necessary lawyer skill." Id. at 126.

${ }^{128} I d$. at 150.

${ }^{129} \mathrm{Id}$. at 150 . "[P]rofessionals, such as lawyers, are constantly working with the feelings of their clients, and it is a technical necessity that they know how to deal with them. They must learn how to objectify these subjective aspects of their work." Id.
} 
today this may not be a novel pedagogical approach, ${ }^{130}$ Watson's goals in using this technique were rather unique. In addition to making explicit the emotional lives of his students, Watson sought to introduce his students to the power of the unconscious, ${ }^{131}$ as well as to the power of nonverbal communications. ${ }^{132}$ By focusing on these aspects of human interaction, Watson sought to cultivate insight into how human beings communicate. Whereas students honed their verbal skills in other arenas of the law school's curriculum, they nurtured their intra- and interpersonal skills in Watson's class. Advocating the pervasive approach to the development of professional skills, Watson asserted that the techniques he used could easily be adapted to virtually any course; all that is required is the professor's willingness to do so. ${ }^{133}$

${ }^{130}$ For example, in my course on Professional Responsibility, I rely heavily on simulations and videos to place students, to the extent possible, in the sorts of situations in which they are likely to experience ethical dilemmas in actual practice.

131“"The second purpose of these exercises is to demonstrate, without undue anxiety, the fact of unconscious mental life and how it influences behavior. Any class hour is filled with manifestations of unconscious and uncontrolled attitudes or feelings into the classroom situation." Id. at 150-51.

${ }^{132} \mathrm{Id}$. at $151-52$.

${ }^{133} \mathrm{Id}$. at 152 . Watson went on to describe several of the specific exercises he used in his course:

For example, I have a movie of an expert interviewer talking with a family about their emotional problems. He demonstrates beautifully the principles of utilizing verbal and nonverbal communication to find out what lies beneath the surface in a personal interview. The movie is run briefly, for approximately 5 minutes. Very little has been said about the family problems; and the symptom which brought them to the hospital has only been identified in its most superficial manifestation. However, the class observers will have had lengthy contact with the family member and by this I mean a whole 5 minutes and from their observations they may surmise the nature of the problems. I then turn the movie off and press the class to "free associate" about what they think is going on in the family. The pooled observations and reactions of the class, hard pressed by me to go far beyond their level of credulity, develop a detailed description of the family members, their attitudes and behavior, and the different roles they play. I tabulate the observations on a blackboard so that in approximately 20 minutes there is a fairly complete description of each member of the family and his problems. The next step is to turn the movie back on and allow it to speak for itself. The group is inevitably dumbfounded by the accuracy of their "speculations." This gives the class a strong tentative belief in the proposition that all human beings share with the most expert observer the sensitive perception of other persons. It is only in the realm of explicit cognition that the expert is more qualified than the laymen. This exercise gives valuable impetus to these students to begin to develop this skill.

Id. at 154-55. In another example, Watson described using "a series of short mimeographed episodes which I know to be filled with strong emotional undercurrents" involving lawyers with a difficult client problem "of the sort which could drive [the lawyers] to drink." He then asked a student to state "the facts" of the case, picked up on some statement which the student slightly or grossly distorts, and asked the student to elaborate:

The class then establishes that the student has distorted the case, and following a statement by me that this distortion is not likely to be the product of poor preparation, we begin to wonder why the distortion took place. What hidden factors in the case caused this particular student lawyer to make such a gross error of perception? The exploration into this question raises additional psychological factors which must be apprehended and understood... By this means the students are taught how emotions can distort reason, and they begin to apprehend ways they can use to become sensitive to the risk, even if they cannot resolve them alone.

Id. at 155-56. See also Andrew S. Watson, Teaching Mental Health Concepts in the Law School, 33 AM. J. ORTHOPSYCH. 115, 118-20 (1963) (describing similar exercises): 


\section{B. Re-Imagining Legal Education}

Many of Watson's ideas might be implemented by any law school currently in existence were it so inclined. ${ }^{134}$ The ideal opportunity for designing a legal education program that might pervasively cultivate emotional intelligence, however, would be at its outset: at the time of conceptualization and creation of a new institution of legal education. When CUNY Law School opened its doors in 1983, it was unlike any extant law school, with a unique program and curriculum designed to train students to pursue public sector law. ${ }^{135}$ At my own institution, we are currently undertaking the project of rethinking our educational program, in anticipation of a move in the next few years to a new state-of-the-art building that will share a campus with a relatively new state court complex and a brand new federal courthouse. For some time now, we at Touro have been excited about the possibilities of using this unique location to enhance our program, and since Spring 1998 a working group of the faculty have been rethinking the goals of legal education and how they may best be implemented at our new home. Several key aspects of the program have emerged, and as of this writing we have presented a first report to the faculty. ${ }^{136}$

There are exciting opportunities for integrating many of Watson's ideas into our new program. ${ }^{137}$ One of the critical components of the new curriculum is an enhanced and deliberate emphasis on the development of lawyering skills and values to complement the traditional emphasis on knowledge. Another element is to structure verticality into the curriculum, so that each year builds on the

Throughout this process, the emotional responses of the class are related to the helpless and hopeful feelings that clients bring into an interview, as well as what this will mobilize in the lawyer.

$I d$. at 119 . Although he claimed that any willing professor might use his methods, the psychoanalytic skill he brought to the group dynamic process of the classroom, see id. at 118-19, argues forcefully for having a social scientist or psychiatrist with training and skills similar to those of Watson on a law faculty. See Silver, supra note *, at 310 .

${ }^{134}$ Many law schools have already done so. See, e.g., John B. Mitchell et al., And Then Suddenly Seattle University Was On Its Way to a Parallel Integrative Curriculum, 2 CLIN. L. REv. 1 (1995) (describing project at Seattle University Law School); Eleanor W. Myers, Teaching Good and Teaching Well: Integrating Values With Theory and Practice, 47 J. LeGal Educ. 401 (1997) (describing project at Temple University Law School); Watson, Teaching Mental Health Concepts in the Law School, supra note 133, at 120-22 (noting other law schools' attempts to introduce psychodynamic concepts). See also GUINIER ET AL., supra note 33, ch. II, Becoming Gentlemen, n. 246 (citing numerous experiments in legal education).

${ }^{135}$ See Charles R. Halpern, A New Direction in Legal Education: The CUNY Law School at Queens College, 10 Nova L. J. 549, 549 (1986); Howard Lesnick, Infinity in a Grain of Sand: The World of Law and Lawyering as Portrayed in the Clinical Teaching Implicit in the Law School, 37 U.C.L.A. L. REv. 1157, 1184-85 (1990); Leonard D. Pertnoy, Skills is Not a Dirty Word, 59 Mo. L. REv. 169, 178-79 (1994); Nancy Zeldis, Breaking With Tradition: After Tough Times, CUNY Law School Retrenches, 76-SEP A.B.A. J. 60, 61 (1990).

${ }^{136}$ First Report to the Faculty from the Central Islip Planning Committee, May 1999 [herein after REPORT] (on file with the author).

${ }^{137}$ Although what follows reflects the work of the Central Islip Planning Committee, I must add two important caveats. One, the ideas proposed in the Report, id., are preliminary proposals and have not yet been adopted by the faculty. Two, the emphasis on the development of personal skills in the proposed curriculum is my own and does not necessarily reflect the views of other members of the Committee. 
knowledge, skills, and values acquired during the prior year. To maximize the achievement of learning objectives in all three arenas, we intend to expand opportunities for problem-based learning. ${ }^{138}$

By identifying the attributes we hope students possess on graduation from law school, we necessarily had to focus on our vision of The Good Lawyer. In addition to the MacCrate Report, ${ }^{139}$ we were guided by Karl Llewellyn's ideas that the good lawyer should possess skills and wisdom, "practical, effective, persuasive, inventive skills for getting things done," and "wisdom and judgment in selecting the things to get done." 140 The good lawyer "is respectful of human dignity, and is committed to social justice, fairness, equality and other values of the professional community."141 The law is a "calling" and the good lawyer should possess "professional qualities that include integrity, honesty, trustworthiness, compassion and faithfulness.... Although dedicated to truth, the good lawyer is tolerant of ambiguity and diverse points of view, and has a capacity for empathy and imagination that allows for the complexity of social relations and a wide range of human activities, behaviors, motivations and interests."142

Implicit in at least some of these (compassion and capacity for empathy in particular) are concepts of personal intelligences. These characteristics need to be explicit. I would add Watson's goals of an appreciation for the emotional complexities of human reactions, including the good lawyer's ability to maintain the appropriate balance between empathy and objectivity, an appreciation of the power of the unconscious, and the ability to recognize, understand, and use nonverbal communication.

We are discussing the possibility of a first-year, two-semester Lawyering course in the new curriculum, which would provide the opportunity to introduce our students to problem-based learning and the importance of developing legal skills and values, as well as knowledge, from the onset of their law school education. Students will learn that lawyering is about the client. ${ }^{143}$ They will learn that not only does good lawyering require common sense, practical wisdom, sound judgment, creativity, and emotional intelligence (as well as legal knowledge and skills), ${ }^{144}$ but also that being a creative problem solver means "that not all problems require legal solutions; and not all legal problems require a lawsuit." 145

The lessons of the first-year curriculum will be reinforced throughout the next

${ }^{138}$ See, e.g., Steven Jonas, Medical Mystery: The Training of Doctors in the United States Problem-BASED LEARNING, 352-56 (1978).

${ }^{139}$ See Section of Legal Educ. and Admissions to the Bar, Am. Bar Ass'n, Legal Education and Professional Development-an Educational Continuum: Report of the Task Force on Law Schools and the Profession: Narrowing the Gap (1992).

${ }^{140} \mathrm{Karl}$ Llewellyn, The Crafts of Law Re-Valued, 15 RockY MTN. L. Rev. 1, 2-4 (1942).

${ }^{141}$ REPORT, supra note 139 at 7.

${ }^{142} I d$. at $7-8$.

${ }^{143}$ 'Just as doctors should learn in medical school that they must treat the patient, and not the patient's disease, lawyers must learn to serve their clients, and not just their clients' legal 'issues.'" Id. at 12 .

${ }^{144}$ Id. at $12-13$.

${ }^{145}$ See Kerper, supra note 41, at 354. Using the infamous tort liability case of Palsgraf v. LIRR as an example, Kerper suggested a reformulation of plaintiff's problems: 
2 years ${ }^{146}$ of law school. The second year may incorporate "practice modules" to be linked to core courses such as Business Organizations, Criminal Procedure, Evidence, Family Law, Sales, and Trusts and Estates. The practice modules would introduce the students to various skills common to practice in the corresponding core subject matter areas. ${ }^{147}$

The second year, therefore, will serve as a bridge between the introduction to lawyering in the first year and the more sophisticated experiential learning to take place in the third year. ${ }^{148}$ The third-year curriculum, inspired by medical school education and designed to take maximum advantage of our new court-based location, ${ }^{149}$ would include, for each student, two practice "rotations.". Third-year students would spend substantial time in either an in-house clinic or an externship placement. ${ }^{150}$ In both instances, the experiential component would be complemented by a classroom component, designed to maximize the educational benefits derived from the placement.

The thrust of the entire proposed curriculum then will be to integrate the theory, the doctrine, and the practice of law with the goal of having the students' experiences in law school and in their placements reinforce one another. There would be no gap between doctrine and practice, so that students would understand what challenges and opportunities lie ahead for them in their lives as lawyers. At

Mrs. Palsgraf's problem was that she was poor, that she had developed a speech impediment which seriously impacted her ability to get better employment, and that she was having difficulty communicating with, and caring for, her children. The problem clearly had multiple emotional associations having to do not only with Mrs. Palsgraf's mental health, but also her relationship with her daughters.

...

If Mrs. Palsgraf's problem were viewed from the perspective of her daughters, one would suspect they were less concerned with their relative poverty than they were for their mother's mental health.

Id. at 368 .

${ }^{146}$ I refer to 2 rather than 2 or 3 years of law school both for simplicity's sake and because the Committee's ideas for implementing this in our day and evening part-time divisions is not as far along as it is for our full-time program.

${ }^{147}$ See REPORT, supra note 136 at 16 :

In addition to offering exposure to a variety of practice skills, the practice modules would emphasize issues of professional responsibility and introduce students to the specialized knowledge related to practice in the subject area. Thus, for example, Family Law could be taken alone as a three-credit course or as a three-credit course linked to a two-credit practice module perhaps consisting of skills in alternative dispute resolution, drafting and advocacy. Similarly, Trusts \& Estates could be taken as a three-credit course or linked with a two-credit practice module that might include drafting, counseling and basic training on financial planning. The practice module for Criminal Law and Procedure might include counseling, advocacy, and factual investigation, and the practice module for Business Organizations might include drafting, reading financial statements, and counseling. Similar practice modules would be offered for Sales and for Evidence.

${ }^{148} I d$. at $15-16$.

${ }^{149}$ In addition to our proximity to the courts, plans include creation of a center that would house a variety of public interest organizations. $I d$. at 16 .

${ }^{150}$ One of the interesting prospects we are considering is the possibility of a hybrid between an in-house clinic and an externship, facilitated (we hope) by the "on-site" presence of public interest organizations, government offices, and courts. See $i d$. 
each juncture, I would hope, we will employ the wisdom of educational theorists such as Gardner and Salovey so that our students integrate into their visions of lawyering an appreciation of the importance of personal skills and emotional intelligence.

We must do this pervasively, but we need not always do it explicitly. Much of what we can teach our students can be conveyed through modeling and mentoring. ${ }^{151}$ If we ourselves demonstrate both our rational and our emotional capabilities, our students are more likely to do the same. If party names in cases (like Mrs. Palsgraf ${ }^{152}$ ) can be humanized, then it will be easier for our students to reconceptualize clients' problems. If we provide our students with multiple opportunities, through simulation and actual client contact, to try on their roles as lawyers and try out a variety of personal skills, then our students are more likely to enter practice with all the equipment they need to be good lawyers.

\section{Alternative Stories}

1. One story. Imagine another story. Vivian Bearing, having recently received the devastating news of her advanced ovarian cancer, arranges a consultation with her attorney, Robert Morton, ${ }^{153}$ to put her affairs in order. She considers Mr. Morton "her attorney" not because she uses his services frequently but because she uses them at all. He is listed in her personal telephone book not under "M" for "Morton," but under "A" for "Attorney." She has used an attorney infrequently, but always advisedly; once, when she bought a house, and twice more, to prepare and revise her will. The first time she had a will prepared was when she turned 21, a year after her father died. ${ }^{154}$ She had Mr. Morton revise her will when she was 42 , a month after her mother died. ${ }^{155}$ Having no surviving blood relatives with whom she had any personal connection, she resolved at that time to bequeath her entire (albeit modest) estate to the English Department of her university. Now that she has received a (probable) death sentence, she determines it wise to review her will once again and make appropriate legal arrangements in anticipation of the eventualities about to unfold. She is even considering making a substantial bequest to cancer research.

[The Scene: A well-appointed office, much mahogany. Robert Morton is seated behind a large desk. Vivian comes in and sits on a hard chair on the other side of the desk.]

\footnotetext{
${ }^{151}$ See GUINIER ET AL., supra note 33, ch. III (Models and Mentors):
}

I do not object to being a role model, even if I had a choice about the matter, which I probably do not. Indeed, I do feel special responsibilities as a black woman law professor. But in my own eyes, I am a mentor, more than a role model. I hold my students to high expectations of themselves, not of me. I facilitate their learning, not my being. I view teaching as a reciprocal, interactive relationship that is primarily about their education.

Id. at 90 (emphasis in original).

${ }^{152}$ See Kerper, supra note 41.

${ }^{153}$ That this attorney bears the same name as the barrister in THE WINSLOW BoY is of course entirely coincidental.

${ }^{154} \mathrm{~W}_{\mathrm{IT}}$, supra note 7 , at 23.

${ }^{155}$ Id. 
RM: Professor Bearing. Good to see you. What can I do for you today?

VB: I have received some rather unfortunate news. It appears I will probably be leaving this world in the not too distant future. I have recently been diagnosed with stage four ovarian cancer. There is no stage five. ${ }^{156}$

RM: I'm so sorry to hear that. That must be a great shock. How can I be of service?

VB: Well, I may want to revise my will. And I would like to make any necessary arrangements for the disposition of my remains and just generally make sure all of my affairs are in order.

RM: Of course. It was wise of you to come in. In fact, I have a checklist that you can take home with you that lists everything that someone in your situation should want to consider at this time. It includes revising your will, appointing a power of attorney, preparing a living will and a health care proxy. Other things, too. It's quite thorough. And it explains what all the terms mean, what the various documents are for, and so forth. What I would suggest is that you take it home, go over it, decide what actions you wish to take, mail the checklist back to me so I can go over what you have indicated, and then we can make another appointment to see where we go from there. How does that sound?

VB: That would be-fine.

RM: Good. My secretary will give you the checklist on your way out. And Vivian, I am very sorry. You are very brave. ${ }^{157}$

VB: Yes. Thank you.

[Vivian exits.]

It is likely that Vivian left this meeting satisfied that she had chosen the right lawyer. Robert Morton was thorough. ${ }^{158} \mathrm{~A}$ checklist. Excellent. Nothing would be overlooked. She would make the decisions and let him know. And in only 15 minutes! The hollow, empty feeling she had been experiencing ever since the news of her diagnosis was still there. But it was no worse.

2. A different story. Now suppose, instead, having heard that Robert Morton had unfortunately dropped dead of a heart attack the year before, Vivian calls and

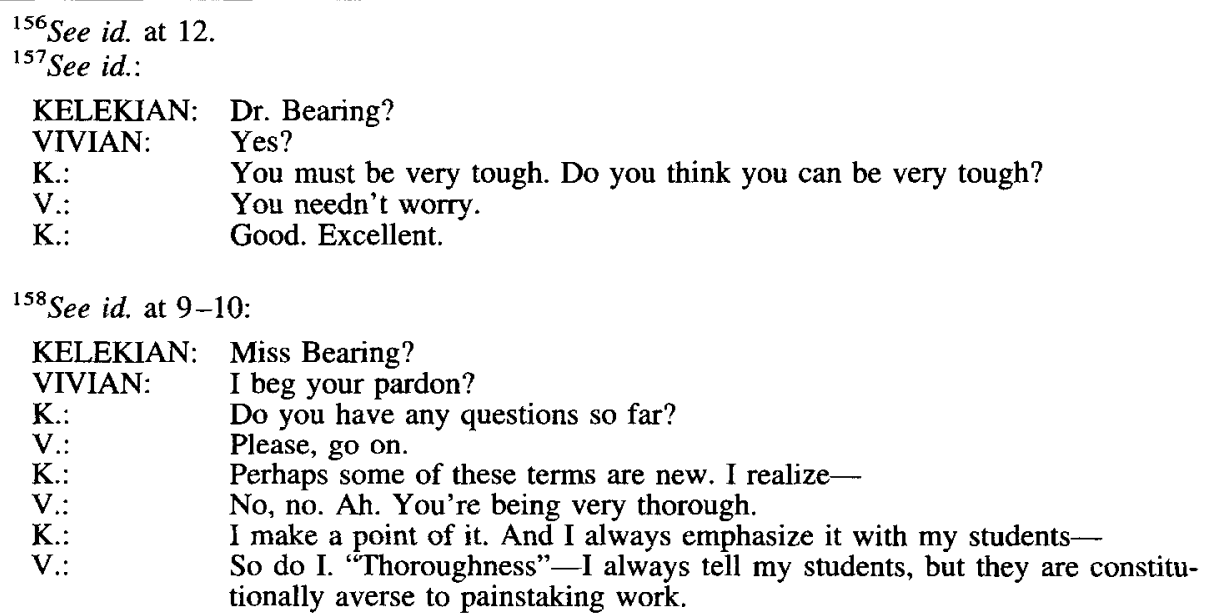


receives a referral from the local bar association. She makes an appointment to see one Pat Adams, a lawyer who specializes in elder care. ${ }^{159}$

I am not going to write this script, but I would like to suggest some things that will be different. The room will be different: less wood, more color, comfortable chairs, a couch, a coffee table. The desk is off in a corner; it serves the function of supporting Pat's computer, telephone, and paper work. Pat will offer Vivian a seat on the sofa and take one of the chairs. Pat will ask if Vivian would like some coffee or juice before they begin. Pat will already know from an intake form completed beforehand why Vivian has made the appointment. Pat will inquire into how Vivian is feeling, how she is doing, and ask how she can help. Pat will spend a couple of hours with Vivian, and during that time they will discuss many things. Pat will explain what a power of attorney is, a living will, a health care proxy. Pat will explore changes Vivian may wish to make to her will. Pat will listen to verbal and observe nonverbal cues from Vivian about Vivian's concerns and fears. Pat will learn that Vivian, in addition to having no close family, has no close friends. Pat may suggest that now, or at some point in the future, Vivian may want to speak with a counselor, one perhaps with whom Pat works closely. Before Vivian leaves, Pat will arrange a follow-up appointment, in advance of which there will be drafts of the various documents prepared for Vivian's review. Pat will tell Vivian that if at any time Vivian is too ill to come to the office, Pat will meet with Vivian at her home, or at the hospital.

We may not be sure how Vivian will respond to Pat. Vivian may remain guarded, remote, ascerbic - this time. However, she is unlikely to have any complaints either. The reasons for which she sought counsel will be addressed. She will be able to put her affairs in order. But a larger door will have been opened. And as Vivian continues to meet with Pat, she may decide to go through that door. At some point in her difficult, painful journey toward death, Vivian may tell Pat she would like to speak with a counselor. Pat will be glad to facilitate that meeting.

Pat learned much of this in law school.

\section{Conclusion}

The re-imagination of legal education for the millennium-an exciting and daunting task-should include a refocusing of our collective attention on the human aspects of lawyering. As technology tugs in one direction, lawyers must not lose sight of the human beings with whom we work. ${ }^{160}$ Traditionally, legal education has browbeat emotional reactions out of law students. This must end. Legal educators should affirmatively and deliberately endeavor to cultivate emotional intelligence, to develop the intra- and interpersonal skills essential to good lawyering. We need to do this for at least two compelling reasons: to increase

${ }^{159}$ That this attorney bears a similar name to that of Dr. Patch Adams is entirely coincidental.

${ }^{160} \mathrm{An}$ interesting comparison is that as technology increases the ability to diagnose more and more diseases, many medical practitioners are apparently moving away from conducting routine hands-on physical exams of their patients. This is causing considerable concern among many physicians about the effect this has on the importance of physician-patient relationships. See Abigail Zuger, Are Doctors Losing Touch with Hands-on Medicine?, N.Y. Tomes, July 13, 1999, at F1, col. 1. 
lawyer satisfaction and to better address clients' needs and concerns. Examples from popular culture-like Wit, Patch Adams, and The Winslow Boy-highlight the detrimental effects of ignoring emotional issues for professional and client alike. We can imagine a better future.

We in legal education must seize the opportunity to address these deficiencies and to build into our curriculum possibilities to develop emotional intelligence. ${ }^{161}$

Other important questions must be left to another day. These include how we can assess personal skills, both in terms of our admissions procedures and in order to evaluate whether our students learn the skills we endeavor to teach. ${ }^{162}$ What I propose raises questions regarding faculty hiring decisions as well. ${ }^{163}$

That Watson and others wrote of the importance of developing personal skills in law school over 30 years ago ${ }^{164}$ attests to the probably intense resistance to the ideas I propose. ${ }^{165}$ Yet if experiments at schools like my own are successful in increasing lawyer and client satisfaction through the development of skills and attitudes that validate the human dimension of lawyering, that will be a rich foundation on which other institutions of legal education may build in the future.

Perhaps some day all lawyers will have learned this in law school.

${ }^{161}$ We must guard against diminishing the interpersonal intelligences with which at least some of our students enter law school, and we must provide opportunities to remediate any deficiencies in these intelligences among our students who have not previously developed them. See Silver, supra note *, at 308 (preferring that students develop awareness of and sensitivity to psychological and emotional effects before law school).

${ }^{162} \mathrm{I}$ am less concerned than are social scientists like Gardner and Salovey as to whether emotional intelligence can be tested and verified in the manner in which we measure such things as IQ. See, e.g., GARDNER, Frames of MiND, supra note 3, at 66; Gardner \& Hatch, supra note 14, at 6; Salovey \& Mayer, supra note 5, at 191-93. However, the question of whether we can evaluate students' potential to develop emotional intelligence as part of our admissions process, or assess students' achievement of personal skills as part of our evaluation process, is ultimately as important as to how we introduce such education into the law school curriculum.

${ }^{163}$ Not only does it raise the question as to whether we wish to include a behavioral scientist on our faculty, it may affect what skills we look for in candidates for all of our teaching positions.

${ }^{164}$ For a discussion of others who have written about the psychological and human relations skills important to lawyering, see Silver, supra note *, at 283-89.

${ }^{165}$ For some cautious optimism that such resistance may be yielding, see id. at 289-92. 